\title{
COMMUNITY PARTICIPATION PATTERN IN THE PLANNING OF ISLAMIC EDUCATION FUNDING IN TAMAN PENDIDIKAN AL- QUR'AN(TPQ) IN BANYUMAS REGENCY, CENTRAL JAVA, INDONESIA
}

\author{
Sunhaji \\ Institut Agama Islam Negeri Purwokerto \\ Purwokerto, Banyumas, Central Java, Indonesia, 53126 \\ E-mail: a.sunhaji@gmail.com \\ Sutrimo Purnomo \\ Institut Agama Islam Negeri Purwokerto \\ Purwokerto, Banyumas, Central Java, Indonesia, 53126 \\ E-mail: sutrimopurnomo92@gmail.com
}

\begin{tabular}{|c|c|c|}
\hline Received: & Revised: & Approved: \\
$18 / 04 / 2020$ & $20 / 05 / 2020$ & $25 / 06 / 2020$ \\
\hline
\end{tabular}

DOI: https:// doi.org/10.32332/akademika.v25i1.2015

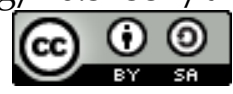

Community Participation Pattern in The Planning of Islamic Education Funding in Taman Pendidikan Al-Qur'an (TPQ) in Banyumas Regency, Central Java, Indonesia Licensed Under a Creative Commons AttributionShareAlike 4.0 International License

\section{Abstract}

This study was aimed at examining the pattern of community participation in the planning of Islamic education funding, especially in the Taman Pendidikan Al Qur'an (TPQ). This research is important because many Islamic educational institutions had low standard quality and even stopped their activities because of weak education funding, including in the realm of financial planning. Community participation is considered appropriate for strengthening education financing planning as a form of equitable democracy, which means that the community has the right to get quality education and is obliged to provide funds. This research is qualitative descriptive field research with case studies as its approach. Data collection techniques used were observation, interviews, and documentation, while the analysis of this research follows the stages of data reduction, data presentation, and inference. The obtained data shows that the presence of active community participation with cultural religious 
functional patterns in the planning of Islamic education financing at TPQ in Banyumas Regency, Central Java indicates an increase in awareness and serious attention of the community towards religious education for their children. Therefore, it is time for Islamic education institutions to be able to utilize this momentum as part of efforts to improve the quality of Islamic education through strengthening education funding.

Keywords: Community Participation, Education Funding, and Islamic Education

\section{A. Introduction}

The rapid development of Al Qur'an education institutions indicates that social awareness of the importance of quranic literacy is increasing, and the presence Al Qur'an education institutions in the midst of society is increasingly needed. The institutions have a fundamental mission, i.e., to introduce and instill the values of the Qur'an from the early age. ${ }^{1}$ One kind of AlQur'an education institutions that is developing in Indonesian society is Taman Pendidikan Al Qur'an, or well-known as TPQ.

The practice of TPQ has a legal basis. In addition, the role of TPQ has also been approved by the government as a kind of education, and it serves as one of the strategies in increasing Indonesian human resources who believe in and fear God Almighty. These roles and functions are stipulated in Law No. 20 of 2003 concerning the National Education System, over Article 3. The article states that national education functions to develop the ability and shape the character and civilization of a dignified nation in order to educate the life of the nation, aiming at developing the potential of students to become human beings who believe in and obey God Almighty, have good character, be healthy, have knowledge, be capable, creative, independent, democratic and responsible. ${ }^{2}$ Meanwhile, in article 30 paragraph (1) through (5) in the National Education System Law, which specifically addresses religious education, the following matters are mentioned. First, religious education is carried out by the government and/or community groups of religious adherents, in accordance with statutory regulations.Second, religious education functions to prepare

1Tim Direktorat Pendidikan Diniyah dan Pondok Pesantren, "Pedoman Pembinaan TKQ/TPQ" (Direktorat Jenderal Pendidikan Islam Departemen Agama RI, 2009).

2Tim Penyusun, Undang-Undang No. 20 Tahun 2003 Tentang Sistem Pendidikan Nasional (Yogyakarta: Pustaka Pelajar, 2011). 
students to become members of the community who understand and apply the values of their religious teachings and/or become religious scholars. Third, religious education can be held on formal, non-formal and informal education paths. Fourth, religious education takes the form of diniyah education, Taman Pendidikan Al Quran (TPQ), pesantren (islamic boarding schools), and other similar forms.Fifth, the provisions regarding religious education as referred to in verse (1), verse (2), verse (3), and verse (4) are further regulated by Government Regulation. ${ }^{3}$ From these several articles and verses, it is expressly shown that the TPQ as one of the institutions of religious education contributes and occupies an important role and position in achieving the goals of national education, namely to form Indonesian people who believe and have faith in God Who Almighty and have noble character.

Ideally, the legal recognition and massive existence of TPQ in the community, as explained above, is also accompanied by the increasing quality of the implementation of professional TPQ. However, the condition of most of TPQ in Indonesia is still far from the ideal. In a research on TPQ, it is found that the management of TPQ currently tends to be done poorly, which gives an impact on the weak condition of TPQ and results in difficulties to achieve the expected improvement for the quality of education services. ${ }^{4}$ Such poor condition of TPQ was also conveyed by Said Agil Husin Al Munawar, ${ }^{5}$ who stated that the condition of madrasas (including educational institutions in general) is currently in an alarming position, where one of the causes is the low participation of the community, which is marked by the decline of community principles based education in madrasa (Islamic educational institutions). In a research conducted by Aliyu A. Kanau and M. J. Haruna, ${ }^{6}$ entitled Towards Promoting Community Participation in Education in Nigeria was obtained the following information:

Poor community participation as a major draw back to the development of education in Nigeria and in view of the fact that government alone cannot shoulder total responsibility of providing education for all and at all levels, the need for strategizing ways of enhancing and encouraging community participation.

${ }^{3}$ Tim Penyusun, 24.

${ }^{4}$ Aliwar Aliwar, "Penguatan Model Pembelajaran Baca Tulis Quran Dan Manajemen Pengelolaan Organisasi (TPA) Jurnal," Al-Ta'dib 9, no. 1 (June 2016).

5Said Agil Husin Al Munawar, "Pendidikan Berbasis Masyarakat Memudar," Media Indonesia.

'Sam M Chan and Tuti T Sam, Analisis SWOT: Kebijakan Pendidikan Era Otonomi Daerah (Jakarta: PT. Raja Grafindo Persada, 2005), 130. 
Some of the research findings indicate that active community participation in education is urgent, even weak community participation can hamper the development and improvement of education services. Therefore, educational institutions are required to develop strategies and efforts to increase community participation in education.

Dasim Budimansyah ${ }^{7}$ emphasized that one of the concrete efforts to boost the quality of education services is to strengthen community participation, namely by accommodating views, aspirations, and exploring the potential of the community to ensure democratization, transparency, and accountability in the management of educational institutions. Public participation is considered important because it is one realization of the essence of just democracy. This means that, in addition to having the right to obtain quality education, the community also has an obligation to participate in the procurement and management of education, which includes the provision of funds, development and maintenance of educational facilities and infrastructure as well as expertise needed in the preparation of programs and their implementation.

Normatively, community participation in education is regulated in Chapter III Article 8 of Law No. 20 of 2003, which states that the community has the right to participate in planning, implementing, monitoring and evaluating educational programs. ${ }^{8}$ Meanwhile, Conyears, as quoted by Yahya Mof, et al., identified three basic needs in community development, one of which was participation in creating and implementing programs. ${ }^{9}$ Thus, collaboration between the community and educational institutions must be developed synergistically. ${ }^{10}$

In Banyumas Regency, Central Java, there have been many TPQs that have been able to actively involve the community in the education funding, including the financial planning stage. In fact, financing is one of the classic problems in the world of education, but there hasn't beena comprehensive solution to overcome this problem. As a result, this poor financialcondition

${ }^{7}$ Dasim Budimansyah, "Peningkatan Mutu Pendidikan Melalui Penguatan Partisipasi Masyarakat," Jurnal Educationist 2, no. 1 (January 2008): 57.

${ }^{\prime \prime}$ Undang-Undang Republik Indonesia No. 20 Tahun 2003 Tentang Sistem Pendidikan Nasional, Bagian Kesatu Hak Dan Kewajiban Warganegara," n.d.

"Yahya Mof and dkk, "Manajemen Partisipasi Masyarakat Dalam Pendidikan Pada MTs Muhammadiyah 3 Al-Furqan Banjarmasin," Jurnal Tashwir Fakultas Tarbiyah dan Keguruan IAIN Antasari 1, no. 2 (2013): 62.

${ }^{10}$ Redaktur Koran Pendidikan, "Mendorong Partisipasi
MasyarakatDalam
http:// wacana.koranpendidikan.com/view/750/mendorong-partisipasi-aktif-
masyarakat-dalampendidikan.html.


has led to the weak quality of Islamic education, and has causedmany Islamic educational institutions, including $\mathrm{TPQ}$, unable to continue their activities.Regarding such a condition, this research is urgent to be carried out as an effort to find solutions for the fulfillment and strengthening of Islamic education funding, especially for non-formal institutions that often have funding constraints. This can be done by following the model carried out by institutions that have been able to meet the needs of education funding independently by involving the active participation of the community. To that end, the his study is expected to be a contribution of ideas and references for Islamic educational institutions that are trying to find alternative solutions to the problems of education financing through active community participation.

The difference between thisstudyand the previous studies is that this study examines the financing of non-formal Islamic education, namely TPQ. There are not many studies related to these institutions and topics. Moreover, most of the previous studies have examined the management of educational institutions in general, which includes planning, organizing, implementing to monitoring, whereas this research focuses on planning studies only. Therefore, the data obtained is expected to be more optimal and can be a practical reference for Islamic educational institutions that will start the management of education funding from the initial stage, namely from planning.

\section{B. Theoretical Review}

1. Education Funding

AbuddinNata ${ }^{11}$ explained that education funding could simply be interpreted as the costs that must be available and needed to carry out education in order to achieve its vision, mission, goals, objectives and strategies. The education funding is needed for the procurement of buildings, teaching and learning infrastructure and equipment, teachers' and education administrators' salaries, and other necessary aspects in holding education. Mulyasa12 emphasized that education funding comprehensively requires the ability of an educational institution or school to plan, implement, evaluate and account effectively and transparently.

From the definitions above, education funding can be understood as the costs that are required to implement education in order to achieve the stated goals, both in the form of money, goods, and labor.

${ }^{11}$ Abuddin Nata, Ilmu Pendidikan Islam (Jakarta: Kencana, 2010), 219.

${ }^{12 E}$ Mulyasa, Pedoman Manajemen Berbasis Madrasah (Jakarta: Direktorat Jenderal Kelembagaan Agama Islam, 2005), 194. 
Education funding at TPQ is interesting to discuss along with changes in teaching and learning activities at the institution. Initially, teaching and learning activities at TPQ were carried out individually and oddly in situations of undeveloped science. At present, teaching and learning activities are carried out specifically and professionally in situations where science and knowledge have developed so fast. In the latter situation, the teaching and learning process can no longer be done part-time by utilizing existing facilities and infrastructure such as mosques or teacher's house. In fact, it requires specific facilities such as classroom, teachers, and other facilities that should be specifically provided for for the learning and teaching activities. In such a situation, education funding must be managed professionally. ${ }^{13}$

Imam Machali and AraHidayat stated that the overall cost of education that a student needs for his education can be classified into several types of education costs, namely: ${ }^{14}$

a. Direct and Indirect Cost

Direct cost is the cost used for school operations. Direct costs consist of capital costs and recurrent costs. Capital costs are used to purchase land for the construction of classrooms, libraries and sports fields, building construction costs, procurement of furniture equipment, replacement costs, and repairs. To determine capital cost, the concept of capital cost per student place is used. Meanwhile, recurrent costs are used to finance educational operational activities, such as to support the implementation of teaching programs, payment of salaries for teachers and school personnel, office administration, maintenance and maintenance of facilities and infrastructure. To calculate the routine costs required by a student per year at school a unit cost analysis is used. The value of unit cost is the value of the unit costs incurred to provide services to a student per year in an education level. Unit costs provide an overview of the amount of costs incurred and the level of service provided.

Indirect costs are costs that support students to be able to attend school. These costs include living expenses, transportation, and other costs. Indirect costs are difficult to calculate because there are no official records. For practical reasons, these costs are not accounted for in planning by administration planners or decision-makers.

b. Social Cost and Private Cost

${ }^{13}$ Nata, 219.

${ }^{14}$ Imam Machali and Ara Hidayat, The Handbook of Education Management: Teori Dan Praktik Pengelolaan Sekolah/ Madrasah Di Indonesia (Jakarta: Kencana, 2016), 404-405. 
Social costs are the costs incurred directly and indirectly by the community. These costs include tuition, book fees, and other costs. Indirect costs include costs such as taxes and levies, in social costs including private costs. The private cost is the direct costs incurred in the form of school fees, tuition, purchase of books, and living expenses for each student. Indirect costs are forgone income after tax.

c. Monetary and Non Monetary Cost

Monetary cost is defined as direct costs and indirect costs paid by society and individuals. Nonmonetary costs are opportunities that are lost because they are used to read books and study.

Thre are some operational stages or procedures in education funding, as explained below. ${ }^{15}$

a. Budgetting

Education budgeting comprises the arrangement of budget, which includes sources of income, expenses for teaching and learning activities, procurement and maintenance of infrastructure, materials and learning tools, honorarium and welfare.

b. Accounting

Education accounting covers two activities, namely: Revenue (receiving funding) and expenditure (using budget). Financial receipts from financing sources are recorded based on management procedures that are in line with the agreed provisions. Likewise, the expenditure of education costs must also be recorded in accordance with a predetermined pattern. Various sources of funds must be used effectively and efficiently, meaning that expenditures must be based on needs that have been planned.

c. Evaluation

Evaluation and accountability for what has been achieved must be carried out in accordance with the stated objectives. Evaluation and accountability for education funding can be identified in three ways. First, the approach to controlling the allocation of funds. Second, the form of accountability of funds, as implemented in the form of monthly, quarterly, annual, or end of period reports. Third, the involvement of supervision from external parties of educational institutions.

\section{Community Participation}

Made Pidarta ${ }^{16}$ defines participation as a person's involvement in an activity. Meanwhile, Huneryear and Hecman ${ }^{17}$ define participation as the

${ }^{15}$ Mulyasa, 81 . 
mental and emotional involvement of individuals in group situations that encourage them to contribute to group goals and share their shared responsibilities. Community in Law No. 20 on the National Education System is interpreted as a group of non-government Indonesian citizens who have attention and role in the field of education. ${ }^{18}$ Based on the definitions of those two words,community participation can be interpreted as the involevement of a person or group of people in an activity.

Community participation emphasizes the direct participation of citizens in decision making in government institutions and processes. Gaventa and Valderma, as quoted by Siti Irene Astuti Dwiningrum, ${ }^{19}$ emphasized that community participation has shifted the concept of participation to a concern with various forms of citizen participation in policy making and decision making in various important aspects that affect people's lives.

Community participation is the involvement of community members in the development and implementation of development programs carried out in local communities. ${ }^{20}$ Community participation has the characteristics of being proactive and even reactive, meaning that the community is taking reason to act, there is an agreement made by all involved; there are actions that fill the agreement; there is division of authority and responsibility in an equal position. ${ }^{21}$

Moeljanto, as quoted by Siti Irene Astuti Dwiningrum, ${ }^{22}$ stated that in the context of local community participation, all implementing partners of a program are really needed. This means that the implementation of a program should maximize community participation in efforts to improve their general welfare. There are several steps that can be taken to encourage community participation: a. Reorientation towards more effective relations with the community through coalition building and communication networks; b. Increased sense of community responsibility for their own

${ }^{16}$ Made Pidarta, Perencanaan Pendidikan Partisipatoris Dengan Pendekatan Sistem (Jakarta: Cipta, 1990), 53.

${ }^{17}$ Huneryager and Hecman, Partisipasi Dan Dinamika Kelompok (Semarang: Dahara Prize, 1992), 30.

${ }^{18}$ Tim Penyusun, Undang-Undang No. 20 Tahun 2003 Tentang Sistem Pendidikan Nasional, 7.

19Siti Irene Astuti Dwiningrum, Desentralisasi Dan Partisipasi Masyarakat Dalam Pendidikan (Yogyakarta: Pustaka Pelajar, 2011), 54.

20Parwoto Parwoto, "Pemberdayaan Masyarakat Dan Prinsip Partisipatif," accessed February 2, 2020, www.library.usu.ac.id/download/fp/06008762.pdf.

21Parwoto, accessed February 2, 2020.

${ }^{22}$ Dwiningrum, 59-60. 
development and increased awareness of their needs, problems, abilities and potential; c. Streamlining communication between various local potentials, so that each element can be more aware of other participatory perspectives; and D. the application of certain principles, namely about life, learning to plan, and work together with the people. Such activities begin with what is known and owned by the community, and this is implemented through giving examples and using approaches that empower them, not just giving help.

The stages of participation according to Cohen and Uphoff, as quoted by Siti Irene AstutiDwiningrum, are explained in the table below:

Table 1

Cohen danUphoff's stages of participation ${ }^{23}$

\begin{tabular}{cll}
\hline No. & \multicolumn{1}{c}{ Stages } & \multicolumn{1}{c}{ Description } \\
\hline 1. & $\begin{array}{l}\text { Decision } \\
\text { Making }\end{array}$ & $\begin{array}{l}\text { Determining alternatives with the community to } \\
\text { come to agreements on various ideas concerning } \\
\text { common interests. }\end{array}$ \\
\hline 2. & $\begin{array}{l}\text { Implementa- } \\
\text { tion }\end{array}$ & $\begin{array}{l}\text { Mobilization of resources and funds. Inthe } \\
\text { implementation of participation, this is a } \\
\text { determinant of the success of the program. }\end{array}$ \\
\hline 3. & $\begin{array}{l}\text { Benefit } \\
\text { Taking }\end{array}$ & $\begin{array}{l}\text { Participation related to the quality and quantity } \\
\text { of results that can be achieved. }\end{array}$ \\
\hline 4. & Evaluation & $\begin{array}{l}\text { Relating to the overall program implementation. } \\
\text { This participation is aimed at finding out how } \\
\text { the program is running. }\end{array}$ \\
\hline
\end{tabular}

Azyumardi Azra ${ }^{24}$ explained that there are several strategies that can be developed to encourage community participation in education, including: a. Increasing community participation in empowering education management; $b$. Increasing community participation in the development of quality oriented madrasa (Islamic educational institutions); and c. Increased community participation in the management of learning resources in the community, so that madrasas are not separate and remain an integral part of Muslim society.

${ }^{23}$ Dwiningrum, 63.

${ }^{24}$ Azyumardi Azra, Pendidikan Islam: Tradisi Dan Modernisasi Menuju Millennium Baru (Ciputat: Logos, 2000), 153. 
The level of community participation in an educational institution can be seen from several indicators as follows:25The level of community participation in an educational institution can be known from several indicators as follows: a. The contribution or dedication of stakeholders in terms of services (thinking / skills), financial, moral, and material or goods increases; b. stakeholder trust in educational institutions increases; c. stakeholders' responsibilities towards the delivery of education have increased; $d$. the quality and quantity of criticisms and suggestions for improving the quality of education increases; e. stakeholder awareness of every step taken by educational institutions to improve quality increases; and $\mathrm{f}$. the decisions made by educational institutions truly express stakeholder appreciation and opinions and are able to improve the quality of education. a. The contribution or dedication of stakeholders in terms of services (thinking / skills), financial, moral, and material or goods increases; b. stakeholder trust in educational institutions increases; $c$. stakeholders' responsibilities towards the delivery of education have increased; $d$. the quality and quantity of criticisms and suggestions for improving the quality of education increases; e. stakeholder awareness of every step taken by educational institutions to improve quality increases; and $f$. the decisions made by educational institutions truly express stakeholder appreciation and opinions and are able to improve the quality of education.

Furthermore, related to the level of power given to the community, Shery Arstein, in Suhirman, as quoted by Siti Irene Astuti Dwiningrum, devides community participation into the following levels:

Table 2

Levels of Community Participation ${ }^{26}$

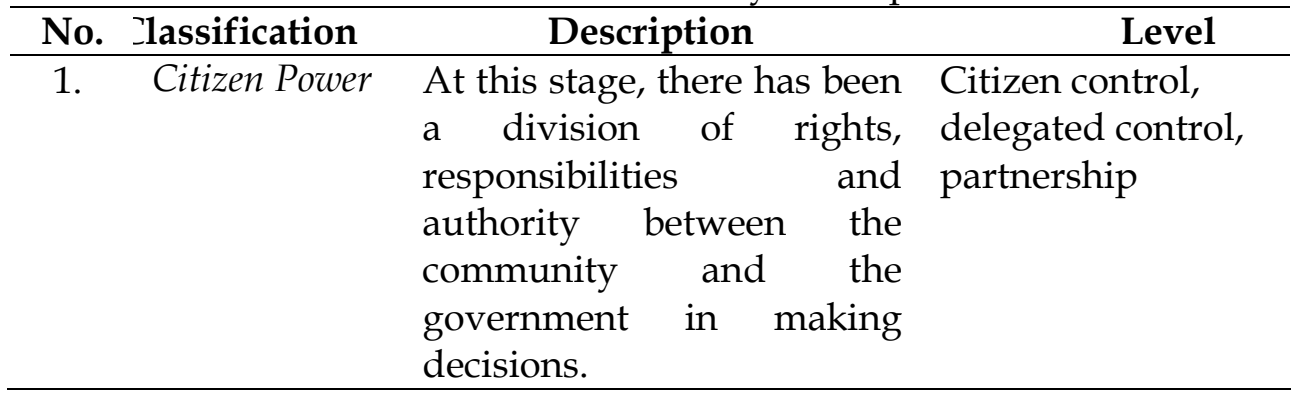

${ }^{25}$ Sri Suharyati, "Partisipasi Keluarga Miskin Dan Manajemen Program Wajib Belajar Pendidikan Dasar Sembilan Tahun Di Banjarnegara" (Tesis, Universitas Negeri Yogyakarta, 2008), 25.

26Dwiningrum, 64. 


\begin{tabular}{ccll}
\hline No. Ilassification & \multicolumn{1}{c}{ Description } & \multicolumn{1}{c}{ Level } \\
\hline 2. & Tokenism & $\begin{array}{l}\text { Just a formality that allows } \\
\text { people to hear and have the } \\
\text { right to vote, but their } \\
\text { opinions have not been } \\
\text { taken into consideration in } \\
\text { decision making. }\end{array}$ \\
\hline $\begin{array}{l}\text { Non } \\
\text { Participation }\end{array}$ & $\begin{array}{l}\text { Community is only made } \\
\text { an object. }\end{array}$ & $\begin{array}{l}\text { Therapy, manipulatio } \\
\text { and }\end{array}$ \\
\hline
\end{tabular}

Based on the levels of participation, it can be assumed that participation able to move the dynamics of society is the one in the level of citizen power. This is because in this level, there has been civil society involvement as an important pillar in mobilizing the community. ${ }^{27}$

The level of parental involvement in educational institutions is not only determined by parents, but also determined by the prevailing education system. Khumas as quoted by Siti Irene Astuti Dwiningrum said that the process of parent involvement in schools / educational institutions arranged in a hierarchical manner can be described as follows:

Table3

Parents Involvement in Educational Institutions 28

\begin{tabular}{cl}
\hline No. Level & \multicolumn{1}{c}{ Description } \\
\hline 1. Spectator & At this level, the involvement of parents in school \\
& is very small, or even there is no involvement of \\
& parents. Parents feel that schools and teachers are \\
& autonomous powers who do not want parental \\
& intervention. School institutions are seen by \\
& parents as a barrier to participation. Activities that \\
& require parental participation are conducted \\
& outside of school. The role of parents is very \\
& limited. Communication between teachers and \\
& parents, either by letter or telephone is very rare. \\
& This form of communication occurs only when \\
& parents have complaints or rejects information \\
& about their children. Even worse, parents show an \\
& overreaction to the poor achievements of children \\
& by openly criticizing schools, punishing children or
\end{tabular}

27Dwiningrum, 65.

${ }^{28}$ Dwiningrum, 74-75. 


\begin{tabular}{ll}
\hline No. Level & \multicolumn{1}{c}{ Description } \\
\hline 2. Support & even physically hurting. \\
& At this level, the involvement of parents in the \\
& school is only at special times when the school \\
& requests it. Tasks assigned to parents can usually \\
& be completed at home and do not require time and \\
& energy. For example, parents go to school to ensure \\
& that their childrenare present; parents check the \\
& child's homework. In addition, parents usually \\
& donate to schools, pay contributions from parent \\
& groups and so on. \\
\hline Engagement & Parent and school relationships respect each other \\
& in an atmosphere of mutual support. Parental \\
& involvement in schools is based on two general \\
& needs, namely: a. to observe school and its effects \\
& on children, b. to show their participation to their \\
& children. The school expects parents to: a. develop \\
& and distribute information resources for schools \\
and communities, b. work as volunteers or as \\
resource persons to share knowledge, skills and \\
special talents with students. The teacher can ask \\
parents to provide transportation facilities and \\
accompany students on field study visits. Even in \\
class, parents can guide students and take them to \\
academic activities under the guidance of the \\
teacher. Parental involvement is in line with \\
expectations for knowing the child's experience in \\
school and the experiences of other children. \\
Parents realize that the function of the school is not \\
only providing skills as work provisions but \\
schools also function to provide provisions so that \\
students have quality life skills.
\end{tabular}


Furthermore, Mulyasa, as quoted by Marzal, ${ }^{29}$ said that indicators of high community participation in the administration of education in an educational institution include: a mutual understanding between schools or educational institutions, parents, the community, and other institutions in the community; b. Helping each other between the school and the community because they know the benefits, meaning, and importance of their respective roles; and c. close collaboration between the school and various parties in the community and they feel proud of and responsible for the success of education in the educational institution or school.

\section{Research Method}

This research is a descriptive-qualitative field study using a case study approach. The research object examined was community participation in the planning of financing Islamic educational institutions in TPQs in Banyumas Regency, Central Java, focusing on the types of Direct Cost financing in the form of Capital Cost and Recurrent Cost. To explore field data observations, interviews, and documentation were used as data collection techniques. In addition, to test the validity of the data, technique triangulation and source triangulation were used. Data reduction, data presentation, and verification and inference are techniques used to analyze data.

\section{Research Findings and Discussions}

In this part, the discussion of the researh results (about community participation in education financing planning in TPQ in Banyumas Regency) begins with reference to what was conveyed by Siti Irene Astuti Dwiningrum, ${ }^{30}$ who stated that participatory planning in the preparation of an educational activities or programs should be carried out through the following stages: problem analysis, potential analysis, and analysis of community interests. The three stages in the preparation of educational program planning involving community participation have been proven to be carried out by the TPQs in Banyumas Regency. The following are a number of TPQs in the Banyumas Regency which have been able to maintain their existence and continue to strive to improve the quality of the education by actively involving community participation.

${ }^{29}$ Marzal Marzal, "Partisipasi Orang Tua Siswa Dalam Kerangka Manajemen Berbasis Sekolah Di MTs Negeri Yogyakarta II" (Tesis, Universitas Negeri Yogyakarta, 2008), 41.

${ }^{30}$ Dwiningrum, 76. 
Table4

TPQs Banyumas Regency 31

\begin{tabular}{cllc}
\hline No. & \multicolumn{1}{c}{ Name TPQ } & Address & $\begin{array}{c}\text { Number } \\
\text { ofSantri/Students }\end{array}$ \\
\hline 1 & Al Ittihad & Teluk & 160 \\
\hline 2 & API Darulmafatihul Ulum & Tamansari & 120 \\
\hline 3 & Asy Syafa' at & Pengebatan & 117 \\
\hline 4 & Fathurrobani 2 & Patikraja & 105 \\
\hline 5 & Misbahul Munir & Pamijen & 75 \\
\hline 6 & An Nur & Sarwodadi & 70 \\
\hline
\end{tabular}

Table 4 shows that the TPQs in Banyumas Regency have identified the number of students. In addition to the information summarized in table 4, information is also obtained that each TPQ carries out a needs analysis. First, problem analysis. One example of needs analysis carried out by TPQ Al Ittihad is a problem analysis. This can be seen from the salary planningfor the teachers (ustaz and ustazah) and their assistants. Every month, TPQ Al Ittihad needs Rp 1,200,000 for teacher salaries, which means Rp. 14,400,000 annually. The amount of money is allocated for the monthly salary of four teachers (teachers), each of whom gets a salary of Rp 175,000, 2assistants,each of whom gets Rp 125,000, and an advisor (also a teacher), who gets $\mathrm{Rp} 250,000$. This is one axample of financial problem analysis of TPQ Al Ittihad.

Analysis of other problems carried out by TPQ Al Ittihad was also seen in the construction of the TPQ building. Community concerns related to the increasing quantity of students drove an idea of having a TPQ building accommodating and good enough for studying. At first, there were only 30 students, and at that time Al Ittihad Mosque was able to accommodate all the students. With the number of santri reaching to 160 people, Al Ittihad Mosque was no longer able to accommodate the students. As a temporary solution, some residents gave up their homes as a place to study for the students, both on the porch of the house, the living room and even the garage of the residents' houses. This condition encouraged residents to build the Al-Ittihad TPQ building.

Second, potential analysis. Potential analysis conducted by a number of TPQ in Banyumas is related to the tuition fee. The need to pay the salaries of teachers and assistants was socialized to santris' parents (or the ones responsible to each santri), and this shows that there was an effort

31“Data EMIS TPQ Kemenag. Banyumas and Ikatan Guru TPQ Kabupaten Banyumas," n.d. 
made by the TPQ management to involve the parents to participate in planning and finding joint solutions for the fulfillment of the wage financing. This sharing information comprises an indicator that the TPQ management has a hope and sees the potential of the parents to share and be able to meet those needs. After TPQ administrator and the the parents deliberated, an agreement was reached that the parents are ready to bear the funding needs of the teacher and assistant salaries by paying tuition fee.

Third, analysis of interests in society. The previous two analyzes undoubtedly show that the designed activities or programs are in line with community interests. The construction of TPQ buildings in Banyumas certainly has an impact and benefit to the community, i.e. the needs for having an accommodating and proper building for their children to study.

Furthermore, there are a number of facts that further strengthen the community participation in TPQ financing planning in Banyumas Regency. The facts are most especially related to the parents' taking part in decisions making. Below are the facts showing the participation.

Decision making on the financing of teacher salaries is carried out jointly between the TPQ and the students' parents. This was done at a parent meeting at the beginning of the TPQ school year. The TPQ organizers explained the funding needs for one year and TPQ organizers asked for parents' opinions and responses regarding the funding needs. The parents also agreed and were willing to pay monthly tuition fee to meet these financial needs. Finally, the planned budget for teachers' salary became a joint decision and agreement between TPQ management and students' parents to be implemented and adhered simultaneously.

Another fact that shows the involvement of the community in making TPQ decisions in Banyumas Regency is the construction of TPQ buildings. The construction of the TPQ building actually originated from concerns and initiations from the community as a result of an increase in the number of santri which led to insufficient capacity in the place of learning, so that residents' houses and even in the people's car garages were used as learning places.

The parents' initiative to build a TPQ building and the TPQ advisor's response to the initiative was an evidence of collaboration in decision making between the community and TPQ managers. The response given by the TPQ advisor is by involving the wider community, namely the leaders of subvillage areas (RT and RW) and leaders of Islamic organizations (Muslimat) where the TPQ is located, i.e., in Teluk Village. All elements mentioned above were held at a meeting, and in the meeting they agreed to build the Al Ittihad TPQ building. Members of construction committee consist of the representatives of every subvillage, which means 
that the community has a direct participation in actualizing a TPQ building. In addition, any decision related to $\mathrm{Al}$ Ittihad involed all elements of the community by their representatives.

Another fact that proves community involvement in TPQ financing planning in Banyumas Regency is the community decision about the tuition fee. The choice and the amount of the tuition fee (infaq) were decided through a meeting of the guardians of the santri and TPQ managers. In addition, the technical implementation was also discussed with the queue guardians and TPQ managers, which included the amount of donations and fund management. They agreed that the funds obtained were fully handed over to class teachers and managed to finance the learning needs of teaching and learning.

Community involvement in making decisions about TPQ financing in Banyumas Regency is in line with Cohen's and Uphoff's statements, ${ }^{32}$ as quoted by Siti Irene AstutiDwiningrum. They stated that community participation in decision making related to community interests was very important and was a form of community involvement in determining the direction and orientation of education implementation. Cohen and Uphoff explained that there are various forms of community participation in decision making, for example attendance at meetings, discussions, contributions of ideas, and responses to programs offered. These forms of community participation can be found in several TPQ in Banyumas as previously explained.

If analyzed further, community participation in TPQ financing planning in Banyumas contains elements of the objectives to be achieved, namely: the process of achievement, time of achievement, and implementation agents. For example, in the planning of funding teacher salaries and their assistants, TPQ managers told parents of santri that the funding plan was a form of their gratitude to the teachers for guiding their children.

The parents have agreed on the payment of santri fees, which includes the amount to be paid and the time of payment. The payment is made every month calculated for one year. Parents of students become the main donors to pay teacher salaries and TPQ treasurers are responsible for distributing teacher and assistant salaries.

The explanation above is in line with Koontz and O'Donnel, as quoted by Imam Machali and AraHidayat, ${ }^{33}$ which defines planning as a rational and systematic thought process abot what to do, how to do, when

32Dwiningrum, 61-62.

33Machali and Hidayat, 20. 
to do, and who do a certain activity so that the activity process can take place effectively, efficiently, and productively and meet the demands and needs of the community.

Another interesting aspect of TPQ financing planning in Banyumas is the managerial aspect, in which some TPQs tend to be able to position teachers and administrators according to their respective tasks. The teachers and their assistants have the main task in the learning process, namely teaching students to read and write the Qur'an. The management has the duty to manage TPQ, especially financial management. In case the assistant teachers receive and record the tuition fee, it is only an additional task to help the administrators and the money is directly given to the management, especially the treasurer, who is responsible for managing the community donations. This indicates that TPQ is able to be professional, namely by making the division of tasks and obligations of each element in the TPQ, both teachers, assistants, administrators and even community involvement.

According to Koontz and O'Donnel, the planning of an activity should also consider the following aspects: what will be done, how to do it, when it will be done and who will do it. These aspects required by Koontz and O'Donnel were also found in the planning of the construction of the TPQ building by involving community participation in it.

The first aspect, according to Koontz and O'Donnel, is what will be done or the purpose of implementing the activity. This aspect can be found in planning the construction of the TPQ building in Banyumas, i.e. to provide a suitable place for students to study. This was done to anticipate the lack of classrooms because the number of students continued to grow. The second aspect is how to do it. This can be seen from the establishment of the TPQ building construction committee and the establishment of a land procurement committee for TPQ building construction. The third aspect is the time of construction of the TPQ building. The fourth aspect is who will carry out the construction of the TPQ building. The executors of TPQ building construction were the surrounding community who were members of the TPQ building committee, which consisted of surrounding community leaders, Heads and administrators of subvillage (RW and RT)local village government (Kelurahan), mosque organizers, and other community components. From the composition of the committee for the construction of the TPQ building in Banyumas Regency, there is no doubt that the community has an active role and participation in the construction of the TPQ building. 
Meanwhile, Mulyasa ${ }^{34}$ explained that education financing planning, which includes the preparation of expenditure budgets, at least includes sources of income, expenditure, procurement and maintenance of facilities and infrastructure, provision of learning materials and tools as well as honorarium/salary and welfare. Based on the data obtained, TPQ in Banyumas, especially the management, has planned the five things stated by Mulyasa.

First, the source of income. In general, the source of income for TPQ education funding in Banyumas comes from the community, which includes parents, TPQ administrators, and even people who have no direct interest in TPQ. For example, the source of funding for teacher salaries and their assistants is funds from students' parents and TPQ administrators. Meanwhile, the source of funds for TPQ building construction in Banyumas involves the wider community, which includes communities outside TPQ, such as private parties and cooperating with several shops to place charity boxes for TPQ building construction, and so on. Then, funding sources for programmed and participatory activities come from parents, TPQ management, and the community around TPQ.

Second, expenditure. In terms of expenditure, the TPQ in Banyumas has made a budget plan that is discussed and agreed upon with the community, especially parents of students. For example salary planning for teachers and their assistants is carried out at the beginning of the school year by holding a consultation between the board and parents to discuss the amount of funds needed to finance it. Other expenses are also carried out by making a budget plan such as the planned cost of the end of year celebration activities and participation in the ta'aruf march where both of these are conveyed to parents to find a solution for the fulfillment of the financing.

Third, procurement and maintenance of learning facilities and infrastructure. In the provision of learning facilities, the TPQ building construction committee submitted a proposal to request a donation for TPQ building construction funds. The proposal includes the required budget details and building specifications made. Related to this aspect, TPQs in Banyumas Regency were not made a planning concerning the provision of learning facilities needed on a regular basis, including budget plans for the maintenance or maintenance of existing facilities. Procurement of learning facilities needed is done incidentally by using students' tuition fees which are managed by each homeroom teacher. Planning for the provision of learning facilities should be carried out by TPQ in Banyumas on a regular

${ }^{34}$ Mulyasa, 81. 
or annual basis because this will also have an impact on the budget planning needed for the provision of these learning facilities.

Fourth, salary and welfare. This is one aspect of the TPQ management's attention in Banyumas. Planning for the salaries of teachers and their assistants is always planned and communicated to students' parents at the beginning of the school year to obtain mutual agreement between parents and TPQ administrators. not only the agreement was built but also the high commitment of parents to support the achievement of the teacher and assistant salary payment plan through regular tuition payments and the amount of tuition fees per student is paid in accordance with mutual agreement.

After an analysis of aspects or stages of education financing planning by involving community participation in TPQ in Banyumas Regency, the next analysis is an analysis of the form and classification or level of community participation in TPQ education financing planning in Banyumas. Basrowi, as quoted by Siti Irene AstutiDwiningrum, ${ }^{35}$ said that there are two forms of community participation, namely physical participation and non-physical participation. Physical participation is the participation of the community (parents) in the form of organizing educational ventures, such as establishing and organizing school businesses, seeking scholarships, helping the government provide buildings for the community and providing books for libraries or other assistance.Meanwhile, non-physical participation is community participation in determining the direction of education.

From the data obtained, the forms of community participation in education financing planning are mostly in the form of joint decisionmaking, such as an agreement in the budget plan for teacher salaries and their assistants, an agreement to fulfill funding needs for year-end celebration activities and participation in the ta'aruf march and agreement on the TPQ building budget plan in Banyumas. Community participation in decision making for these various activities, especially in terms of financial planning, can be an indicator that the form of community participation in TPQ education financing planning in Banyumas Regency is non-physical participation.

Furthermore, according to Shery Arstein, ${ }^{36}$ as quoted by Suhirman, community participation is classified into three levels, namely: citizen power, tokenism, and non participation. Based on the classification, community participation in financing TPQ education in Banyumas can be

35Dwiningrum, 58-59.

36Dwiningrum, 65. 
put into the category of citizen power, in which the division of rights, responsibilities and authority in decision making has taken place. Such a condition was found in community participation in funding TPQ education in Banyumas, ranging from planning in financing teacher salaries and assistance, in which the distribution of rights had occurred, namely the right of teachers and their assistants to get salaries and the rights of students to get education from teachers; distribution of responsibilities, namely parents are obliged to pay tuition fees every month and the responsibility of teachers and assistants to educate students; and the distribution of authority, namely the management has the authority to manage tuition fees from parents and manage them for the payment of salaries for teachers and assistants.

The citizen power indicators also require joint decision making. This indicator was found at TPQ in Banyumas Regency during the planning of teacher and assistant salary payment. TPQ Management invites parents to hold deliberations related to meeting the needs for these funds until mutual agreement is reached. In addition, the construction of the TPQ building in Banyumas was also carried out by a special committee whose members came from the communities around TPQ. In the committee composition, there are chairmen, secretaries, treasurers, and sections. The existence of the composition of the committee shows that there is a division of tasks, authority, and responsibilities of each member.

From various descriptions of community participation in the planning of TPQ education funding in Banyumas Regency, there is one meeting point, namely the characteristics possessed by TPQ in Banyumas Regency in decision making and policy in various activities or programs, which include financing teacher salaries and assistants through SPP santri and the donation of the management, as well as the construction of the TPQ building which involved various elements of the community around the TPQ, ranging from community leaders, RW and RT leaders along with the management, and other figures as TPQ building construction committee.

Other activities concerning joint decision making were also found in programmed activities (year-end celebrations) and participatory activities (ta'aruf marches) involving parents and caretakers. Planning for the financing of these activities is always based on deliberation as a bridge for decision making and joint policy between the TPQ and the community including students' parents. The discourse or proposal can come from the community or the student's guardian, such as an increase in the amount of the SPP, and can also come from the TPQ management or teachers, such as the implementation of the students' infaq program aimed at training 
infiltration students. All proposals are carried out after based on joint decisions through deliberations, including. the technical implementation starts from determining the days and the number of donations (infaq) to management decisions by the teachers for the sake of learning.

\section{E Conclusion}

The existence of community participation in the planning of Islamic education financing in the TPQ (Al-Qur'an Education Park) in Banyumas Regency, Central Java can be an indication of increasing public awareness and serious attention to religious education for children. The society no longer underestimates the importance of religious education. This is actually a positive signal for Islamic educational institutions, especially non-formal ones, which often face problems of funding.

Now is the time for Islamic education institutions, including TPQ, to actively involve the community as part of a form of just democracy, where the public has the right to get quality education, and also has an obligation to support educational needs including responsibility in providing financial support. Thus, active community participation actually has a strategic position and role as part of efforts to improve the quality of Islamic education[.]

\section{REFERENCES}

Al Munawar, Said Agil Husin. "Pendidikan Berbasis Masyarakat Memudar." Media Indonesia.

Aliwar, Aliwar. "Penguatan Model Pembelajaran Baca Tulis Quran Dan Manajemen Pengelolaan Organisasi (TPA) Jurnal." Al-Ta'dib 9, no. 1 (June 2016).

Azra, Azyumardi. Pendidikan Islam: Tradisi Dan Modernisasi Menuju Millennium Baru. Ciputat: Logos, 2000.

Budimansyah, Dasim. "Peningkatan Mutu Pendidikan Melalui Penguatan Partisipasi Masyarakat." Jurnal Educationist 2, no. 1 (January 2008): 57.

Chan, Sam M, and Tuti T Sam. Analisis SWOT: Kebijakan Pendidikan Era Otonomi Daerah. Jakarta: PT. Raja Grafindo Persada, 2005.

Dwiningrum, Siti Irene Astuti. Desentralisasi Dan Partisipasi Masyarakat Dalam Pendidikan. Yogyakarta: Pustaka Pelajar, 2011.

Huneryager, and Hecman. Partisipasi Dan Dinamika Kelompok. Semarang: Dahara Prize, 1992. 
Machali, Imam, and Ara Hidayat. The Handbook of Education Management: Teori Dan Praktik Pengelolaan Sekolah/ Madrasah Di Indonesia. Jakarta: Kencana, 2016.

Marzal, Marzal. "Partisipasi Orang Tua Siswa Dalam Kerangka Manajemen Berbasis Sekolah Di MTs Negeri Yogyakarta II." Tesis, Universitas Negeri Yogyakarta, 2008.

Mof, Yahya, and dkk. "Manajemen Partisipasi Masyarakat Dalam Pendidikan Pada MTs Muhammadiyah 3 Al-Furqan Banjarmasin."

Jurnal Tashwir Fakultas Tarbiyah dan Keguruan IAIN Antasari 1, no. 2 (2013): 62.

Mulyasa, E. Pedoman Manajemen Berbasis Madrasah. Jakarta: Direktorat Jenderal Kelembagaan Agama Islam, 2005.

Nata, Abuddin. Ilmu Pendidikan Islam. Jakarta: Kencana, 2010.

Parwoto, Parwoto. "Pemberdayaan Masyarakat Dan Prinsip Partisipatif." Accessed February 2, 2020. www.library.usu.ac.id/download/fp/06008762.pdf.

Pidarta, Made. Perencanaan Pendidikan Partisipatoris Dengan Pendekatan Sistem. Jakarta: Cipta, 1990.

Redaktur Koran Pendidikan. "Mendorong Partisipasi Aktif Masyarakat Dalam Pendidikan," n.d. http:/ / wacana.koranpendidikan.com/view/750/mendorongpartisipasi-aktif-masyarakat-dalampendidikan.html.

Suharyati, Sri. "Partisipasi Keluarga Miskin Dan Manajemen Program Wajib Belajar Pendidikan Dasar Sembilan Tahun Di Banjarnegara." Tesis, Universitas Negeri Yogyakarta, 2008.

Tim Direktorat Pendidikan Diniyah dan Pondok Pesantren. "Pedoman Pembinaan TKQ/TPQ." Direktorat Jenderal Pendidikan Islam Departemen Agama RI, 2009.

Tim Penyusun. Undang-Undang No. 20 Tahun 2003 Tentang Sistem Pendidikan Nasional. Yogyakarta: Pustaka Pelajar, 2011.

“Data EMIS TPQ Kemenag. Banyumas and Ikatan Guru TPQ Kabupaten Banyumas," n.d.

“Undang-Undang Republik Indonesia No. 20 Tahun 2003 Tentang Sistem Pendidikan Nasional, Bagian Kesatu Hak Dan Kewajiban Warganegara," n.d. 